\title{
Socio-economic changes in the borderlands of the Visegrad Group (V4) countries
}

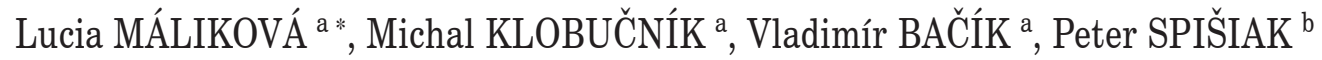

\begin{abstract}
Under the influence of globalization and state integration processes, the importance of a border as a barrier is gradually decreasing. Borderlands are still perceived as specific phenomena, however, not only in terms of historical development but especially in the context of their changing impact on the daily lives of their inhabitants. Along with EU enlargement, the de-bordering process has also become significant in many countries where the borderland played an important role in the past. These include the V4 countries, whose borderlands are the object of this research. In this article we analyze these areas on the basis of selected socio-economic indicators, with a focus on change in the period 2001-2011. As indicated by the Analysis of Variance, the results show the significantly differentiated development of the borderlands, in terms of the individual values of indicators both within the borderland of the EU member states, as well as along the external border of the EU.
\end{abstract}

Keywords: Border, borderland, periphery, indicators, the Visegrad Group (V4 countries: Czech Republic, Slovakia, Poland and Hungary), Analysis of Variance (ANOVA)

\section{Introduction}

Under the influence of globalization and multi-state integration processes, the importance of a border as a barrier is gradually decreasing, which can in many respects evoke a world without limits, without borders (even if we think about national boundaries only). Although the idea of a borderless world is tempting, research on borders and borderlands has emphasized that the boundaries still exist, the significance of borders persists (Best, 2007), but their meaning has become more complex (Paasi, 2012). This phenomenon occurs in the social and cultural sphere as well as along the national borders, as in the case of the EU, where the introduction of the common market for goods, capital, and services often resulted in narrowing their importance only to the delimitation of the geographical territory of independent states. As a result, the status of many borders has changed significantly and is now being reflected in the research literature. This indicates a declining significance of bounded areas, in terms of the rise of the 'space of flows' of capital, information and people (Newman and Paasi, 1988; Anderson and O'Dowd, 1999), and increased cross-border cooperation (Best, 2007; Bufon and Markelj, 2010; Johnson et al., 2011).

EU policies and activities aimed at the mitigation of borders as barriers can generally be described as processes of de-bordering and political restructuring (Nelles and Durand, 2012). Although globalization has challenged us in a positive way and enabled the opening of boundaries which had previously separated us, its impact affects only some cross-border flows, and as Newman (2006) points out, we need to realize the real existence of a hierarchical world with existing borders (whether spatial or aspatial) that are part of our daily lives. At the same time, we need to accept that these borders do not necessarily correspond with national borders; moreover, they often fail to coincide with them (Anderson and O'Dowd, 1999). Such research connotes the interactions and dichotomies between different types of boundaries (e.g. physical, symbolic, political or socioeconomic), as well as an understanding of boundaries as such (Jackson and Molokotos-Liederman, 2015).

Even today, however, we can find places where borders still represent some form of a barrier (e.g. a military, transportation or communication barrier), especially for the territory on both sides of the border - the borderland. Thus, from the perspective of economists, historians and even geographers, the borderland is, due to various negative barrier effects, often considered to be a periphery. And it is not only from a geographical standpoint but also from the perspective of national policies, as a supplement to the already degraded socio-economic status of these areas (Nelles and Durand, 2012), or as a result of the concentration of economic activities in core regions instead (Paasi, 1999; Xheneti et al., 2012). Moreover, in the borderland one finds mostly rural areas which are already very often perceived as peripheral. As many scholars point out, although geographic location is still an important factor, with the decreasing importance of the border as a barrier on the one hand and increasing cross-border cooperation on the other, the perception of any geometric aspects is shifting from looking through the distance of an area to its accessibility. Thus, in the borderland we can identify peripheral as well as core areas (Jeřábek et al., 2004). An example of this is the existence of the area across the Polish (PL), Czech (CZ) and German (DE) borderland zone described by Johnson (2009) as the region of prosperity. Similarly, the area between Bratislava, Vienna and Győr (in a broader sense, Budapest) is known as the 'golden triangle' (Rajčáková, 2005).

The analysis of changes in the meaning of borders and their impact on the borderland is interesting to study, especially in those countries whose borders have changed significantly in the past; for example, as represented by an important line in the formerly politically divided Europe (the so-called 'Iron

\footnotetext{
${ }^{a}$ Department of Human Geography and Demography, Faculty of Natural Sciences, Comenius University in Bratislava, Slovakia (*corresponding author: L. Máliková, e-mail: malikova@fns.uniba.sk)

${ }^{b}$ Institute of Geography, Faculty of Science, University of Pavol Jozef Šafárik in Košice, Košice, Slovakia
} 
Curtain'), and now part of the EU's internal borders. This includes, among others, the V4 countries (Slovakia (SK), The Czech Republic (CZ), Poland (PL) and Hungary(HU) whose borderlands are the object of this research. In fact, we agree with Anderson and O'Dowd's (1999) reflection on the relevance of borderland research - in terms of its comparison and relations with other adjacent regions of the neighbouring state(s).

First, a theoretical framework addresses the issue of the border and borderland and its re-positioning within European re-territorialization and restructuring processes, as well as how the new regional geography ${ }^{1}$ adds emphasis to work on borderlands, while focusing on the Central European countries. This is followed by a section which discusses the methodology for the delimitation of the border, and the relevance of the indicators used in our analysis. Building on this theoretical and methodological background, attention is then given to the analysis of the borderland of $\mathrm{V} 4$ countries, with emphasis on understanding the ongoing socio-economic changes. In the last section we summarize the most important aspects of borderland research, in terms of the Central European space, and the key findings of this research are presented.

\section{Theoretical framework}

This section looks more deeply into the theoretical issues related to the merits of research on borderlands and transboundary space and its position within the new regional geography, in the context of Central European countries. As pointed out by Johnson (2009), Europe is an interesting example of how border regions create a new space for the government, cultural interaction and economic development and, at the same time, it is the transboundary space which helps to address many of the spatial queries prompted by on-going globalization trends. Reflecting on the importance and status of the borderland in theoretical considerations, we must first think about its position within the regional structure of national states. In particular, since the borderland has become the spotlight of many studies due to the spatial changes related to $\mathrm{EU}$ enlargement (e.g. revision or changing the status of borders) (Xheneti et al., 2012), border areas are put into a rather new situation, as they are both marginal within the territorial structure of individual states, while also central in consideration of the EU integration processes (Bufon and Markelj, 2010). We can therefore speak of the so-called conflict of territorial logics, where borders are of vital importance for nation states while at the same time undermine the unity and integration promoted by the EU (Popescu, 2008).

On the other hand, former transition and transformation processes and the current influences of globalization and internationalization are redefining the European space, through locational impact (recreating places from the subcontinental to the local level), and thus articulating a new regional geography (Dingsdale, 1999). Existing links over the national borders have created corridors of co-operation (ibid.), which according to Johnson (2009) play an increasingly important role in the changing territorial structure of the EU. In this context, O'Dowd (2001) even speaks of 'trans-frontier' regions (or cross-border regions, Euroregions) as central to European integration, as an alternative to a Europe of sovereign states. Pikner (2008) adds that the implementation of cross-border structures, such as Euroregions, is a partial aspect of the institutional innovation and shifting territorial configurations within the EU.

It should also be emphasized, that these borders, once perceived as physical barriers, the dividing line between states and geographic space, have been recently considered not only as a geographical space but rather conceptualized as "transformative and evolving processes that are politically, economically and socially embedded" (Xheneti et al., 2012: 317). It is the impact of the border on the territory, i.e bordering and de-bordering processes, which should be in the spotlight of current academic, social, and political discourses (Newman, 2006).

These aspects are just some of the many issues which highlight the apparently strong position of border and borderland issues in the discussions within the new regional geography. Many scholars, however, suggest that there is still enough space for the study of borders and, in particular, cross-border areas, within discussions of the territorial restructuring of Europe (Perkmann, 2003). Supporting the idea that boundaries are in fact parts of rescaling processes, Paasi (2002) justifies the lack of attention paid to the border and borderlands resulting from researchers whose field adopted simplified visions of a borderless world and where the importance of spatiality is underestimated.

Moreover, we can agree with Johnson's (2009) critisism of the emerging studies on restructuring and political rescaling (based on the work of scholars such as Brenner, 2000, 2003 and Gualini, 2004), where the borders and the borderland issues are not sufficiently addressed and often even neglected. Even so, Brenner, highlighting the importance of ongoing rescaling and restructuring processes within Europe, focuses more on the fact that it is the centre or in fact "city-regions that have become key geographical sites in which various trends and counter-trends of state reorganization are being articulated" (Brenner, 2003: 319). On the other hand, Gualini (2004) argues that the omission of cross-border areas in his research is made in order to simplify the interpretation of results. Thus, Johnson's (2009) criticism is justified since, as he argues, transboundary regionalism is closely linked to territorial restructuring processes across Europe, and there are still many questions to be answered in this respect. For instance, as emphasised by Varró (2014), criticisms of statecentrism in studies on cross-border regions have already pointed out deficiencies in terms of a largely one-dimensional perspective, focusing in particular on the territorial and scalar aspects of cross-border regionalism.

We believe that Central European countries (V4 countries in this case), in particular, since they have undergone not only economic transformation but territorial transformation as well (Buffon, 2007), represent an interesting 'experimental' field for the study of how former transition and current globalization processes, transform the status of their borderlands. Even more is this the case when we consider that the fall of the Iron Curtain and EU enlargement resulted, in fact, in some borders disappearing while others were created (Häkli, 2008). As a result of the above-mentioned processes, some parts of their borderlands

\footnotetext{
${ }^{1}$ The 'new regional geography' is a term used by some geographers, mainly in the 1980 s and 1990s, who were engaged in solving the problem of the region by reframing the terms of the study itself. In this regard, region was seen as a medium and outcome of social practices and power relations operating at multiple spatial scales, while serving as a kind of fix. Its critique focuses on insufficiently spatialized social theory and political economy (see Gregory et al. [eds.], 2009).
} 
have been transformed from peripheral areas to areas of interest and economic growth (Stryjakiewicz, 1998), while at the same time the peripheral position of other border areas could have even been exacerbated. As already highlighted, the EU enlargement process itself tended to prioritize the development of central regions, leaving a number of borderlands in vulnerable positions (Xheneti et al., 2012). Moreover, the current spatial structure of these countries (which is now being shaped by Europeanization through the influence of the EU (Dingsdale, 1999)), often does not correspond with the historical form of territorial organization, while persistent cross-border regions (relations and ties) tend to copy the former spatial framework and often do not fit into the current spatial regionalization (Buffon, 2007; Buffon and Markelj, 2010).

Thus, it seems that V4 countries might be a convenient laboratory for analysis of the borderland, cross-border linkages and the diversity/similarity of adjacent areas on both sides of the border. Therefore, in this article we analyze such areas on the basis of selected socio-economic indicators, with an emphasis on the population characteristics of those who live in the borderland. We attempt to somehow connect conventional, traditional approaches accentuating mostly the territorial aspects of peripherality (in terms of geographical isolation, peripheral location - i.e. the borderland), with unconventional perspectives emphasizing aspatial peripherality (peripherality connected not only with a physical space, but with the multiplicity of social spaces which overlap the same geographical area (McDonagh, 2002)).

Our work is based on the assumption that despite the geographical proximity of the analyzed borderlands (Central European countries, neighbouring countries), historical circumstances (transformation processes) and their position in relation to EU (accession to the EU in 2004), differences in changes in indicator variables and also in the level of development and current status between certain areas along and across the border, can be observed. Thus, some parts of the borderland can be considered as peripheral and others as central; as barriers on the one hand and as gateways of interaction on the other (Anderson and O'Dowd, 1999; O’Dowd, 2001).

Based on this general hypothesis, we attempt to answer questions related to the intensity and extent of changes in the selected socio-economic indicators. In particular, we focus on both changes along the border (within the country) and changes between neighbouring areas on both sides of the border (cross-border relations). Since border areas are often at the interface of different economies, environments and cultures, borders can act as barriers resulting in different development paths on both sides of the border (Krätke, 1999; Johnson, 2009). Bearing this in mind, despite the dual functions of the borders, and a frequent weakening status of the border as a physical barrier, there is a kind of imaginary barrier that exists between these countries, which causes differences, and in some areas still represents a dividing line.

\section{Methodology}

The borderland represents an interesting research space not only from the geographical perspective, but also from the perspective of historians and economists. Although 'borderland' is a common research subject in these disciplines, its delimitation is far from being uniform. In academic research we can find a variety of views, procedures and criteria used to define the borderland. As Jeřábek et al. (2004) point out, an exact definition or universal delimitation of the borderland does not exist, since every single discipline studies this phenomenom from a different perspective and the final delimitation of a borderland is adjusted to reach different research objectives. But, in general, we can identify the most commonly-used types of borderland definition, based on prevailing criteria (see Tab. 1).

\begin{tabular}{|c|c|c|}
\hline & Type of delimitation & Criterion and characteristics \\
\hline \multirow{6}{*}{ Objective } & Administrative & $\begin{array}{l}\text { Delimitation based on administrative subdivision (municipalities, districts along the } \\
\text { border, Euroregions in EU). Practical delimitation due to data availability. }\end{array}$ \\
\hline & Geometric / distances perspective & $\begin{array}{l}\text { Delimitation based on the distance from the border area, often using the administrative } \\
\text { criterion. } \\
-15 \mathrm{~km} \text { - definition of the borderland for the purpose of questionnaire surveys } \\
\text { (Jeřábek et al., 2004) } \\
\quad-20 \mathrm{~km} \text { - zone defined on the basis of national legislation (Arnold-Palussiére (1983) in } \\
\text { Jeřábek et al., 2004) } \\
\quad-25 \mathrm{~km} \text { - definiton in various international acts upon adoption of bilateral agreements } \\
\text { on the regulation of cross-border movement of goods and people (Bufon, 2007). }\end{array}$ \\
\hline & Historical & $\begin{array}{l}\text { Delimitation based on common historical development features (e.g. relict boundaries } \\
\text { - now non-existent). }\end{array}$ \\
\hline & Cultural / ethnic dimension & $\begin{array}{l}\text { Delimitation of the borderland as a culturally or ethnically homogeneous area (usually } \\
\text { according to share of ethnic minorities). }\end{array}$ \\
\hline & Political and economic & $\begin{array}{l}\text { For example delimitation based on EU requirements on the possibility of drawing } \\
\text { support for the borderland (borderland as territory with population of } 1 \text { million and } \\
\text { more). }\end{array}$ \\
\hline & Physical-geographical aspect & $\begin{array}{l}\text { Definition based on delimitation by natural barriers (e.g. mountains). This aspect is } \\
\text { currently receding into the background due to technical progress. }\end{array}$ \\
\hline Subjective & Perceptual dimension & $\begin{array}{l}\text { Delimitation based on a subjective identification of people with the borderland. This } \\
\text { approach emphasizes 'bottom-up' delimitation (useful especially in identifying and } \\
\text { building the identity of the borderland). }\end{array}$ \\
\hline
\end{tabular}

Tab. 1: Types of borderland delimitation. Sources: Jeřábek et al., 2004; Bufon, 2007; edited by authors 
Some authors focus on issues of border and borderland without its explicit delimitation, emphasizing its dependence on the definition of the type and nature of the border, especially in terms of the openness and permeability of the border (Džupinová et al., 2008; Jeřábek et al., 2004), or from the perspective of those from one side of the border (Xheneti et al., 2012). Other scholars highlight the problem of spatial scales of boundary construction, which not only plays an important role in the delimitation of the borderland (Johnson, 2009) but also represents one of the major themes in border studies (Newman and Paasi, 1998). Such studies are mostly dedicated to the processes of deterritorialization and re-bordering, generally recognized as rescaling examples (Häkli, 2008), although, as highlighted in the previous section by Johnson's (2009) criticism, there is still a call for a greater implementation of scale within the border issues.

Based on the empirical findings of a case study in the Czech Republic, Vaishar et al. (2011) and Vaishar et al. (2013) point out quite interesting results, that the influence of a state (national) border is the most significant in the first village (municipality) at the border and at the first town (centre) which provides services of a higher rank. For these authors, such territory can be classified as borderland. We may argue that this statement, although it applies to a certain area in the Czech Republic, can not be generalized. At the same time we need to acknowledge that such understanding of the borderland is limiting to a certain extent and with current globalization influence it can hardly be recognized as unambiguous. As mentioned in the previous section, attention is now shifting from the distance of a certain place to its accessibility (Jeřábek et al., 2004). Thus, a distant area with better accessibility (e.g. transport connectivity) to the border may be more affected by the presence of the border itself.

In the context of EU enlargement processes as well as the increasing importance of EU policies (devoted among others also to border regions and borderlands), several scholars have paid attention to borderland research in terms of the formation of new structures: Euroregions (Perkmann, 2003; Johnson, 2009; Nelles and Durand, 2012; and with regard to the analyzed area, for example, Dołzbłasz, 2013; Tokes and Lenkey, 2013); areas allocated on the basis of different levels of NUTS (Wieckowski et al., 2012); and even administrative units of the countries (Kladivo et al., 2012). In general, we can agree with a borderland being interpreted as "the region or area in relative close proximity to the border within which the dynamics of change and daily life practices are affected by the very presence of the border" (Newman, 2006: 150) or, in other words as, "areas in which both economic and social lives are directly influenced by the proximity of an international border" (Bufon, 2007: 4).

\section{Study area}

For our analysis we chose Central European countries, expecially the V4 countries (Czech Republic, Slovakia, Poland and Hungary). This study area was not chosen randomly but rather influenced by several factors:

- these neighbouring countries are located in Central Europe, which combines proximity to the socio-economic situation and particularly historical development. Boundaries as well as the borderland of these countries had been changed considerably in the past (e.g. by forming boundaries of a politically-divided Europe, the so-called Iron Curtain). We also bear in mind the different ways in which these particular historical changes impact on the diverse and contradictory dimensions of borders (Anderson and O'Dowd, 1999);

- in 2004, these countries joined the EU (as a part of the EU enlargement process) and their eastern borders have become part of the external border of the EU. Xheneti et al. (2012) argue that the EU enlargement could only have minimal impact on the socio-cultural basis of these border areas since historical, social and cultural dimensions of these boundaries were stable over time. As recognized in another part of their work, however, the nature of the borderland has changed significantly (the eastern boundary is seen as a periphery, the western boundary as a space for cooperation). It is therefore interesting to see whether and how the EU territorial transformation is reflected in the socio-economic status of these borderlands; and

- several authors have carried out their research within the issue of borders and borderlands in the Central European space, highlighting various aspects. The work of Xheneti et al. (2012) examines the impact of EU enlargement on changes in the spatial characteristics of the border regions related to the redirection of the economy and market flow to the west, resulting in peripheralization of eastern boundaries. In comparison, Turnock (2002) and Perkmann (2003) analyze the creation of CBC regions (cross-border cooperation) as a result of the declining importance of borders and increasing regional initiatives, and Wieckowski et al. (2012) focus their attention on the more closely specified area of transport accessibility and tourism development in the PL/SK borderland. The diversity of these studies shows that borders and the borderlands have become important objects of research, and not only in the Central European space.

Given the diversity of borderland interpretations, as well as the various foci of studies, this research requires a variety of methodologies (Bufon, 2007). In our study we used a relatively simple but sufficient zoning method, buffering, based on the definition of direct air distance from the selected object (state border). This delimitation is based on geometric aspects using the administrative criterion as a zone of municipalities located along the borders. With respect to differences within the analyzed countries (area, length, and width), in the first phase of the borderland delimitation we used several distance zones and spatial relations (Fig. 1).

Using 30 and $50 \mathrm{~km}$ distances proved to be inadequate, especially because of the small territorial size of Slovakia (the shortest width of the country reaches less than $80 \mathrm{~km}$ ). When using a given distance 30 and $50 \mathrm{~km}$, the final delimitation of the research would comprise 1,857 or 2,696 municipalities respectively, representing $63 \%$ or $90 \%$ of all municipalities of the country. Such delimitation of the borderland would significantly affect our interpretation of the results obtained from the research. Moreover, it was also necessary to take into account differences in the size of territorial units (municipalities, districts) or administrative units (NUTS) within the analyzed countries.

After selecting a $20 \mathrm{~km}$ distance zone as the most convenient, it was necessary to select the appropriate spatial operation to obtain the final selection of municipalities and so define the borderland. For this purpose we have chosen the position of the centroid of the spatial unit, which appears to be a suitable approximation of its position for its integration into the distance zone. We excluded another spatial operator, 

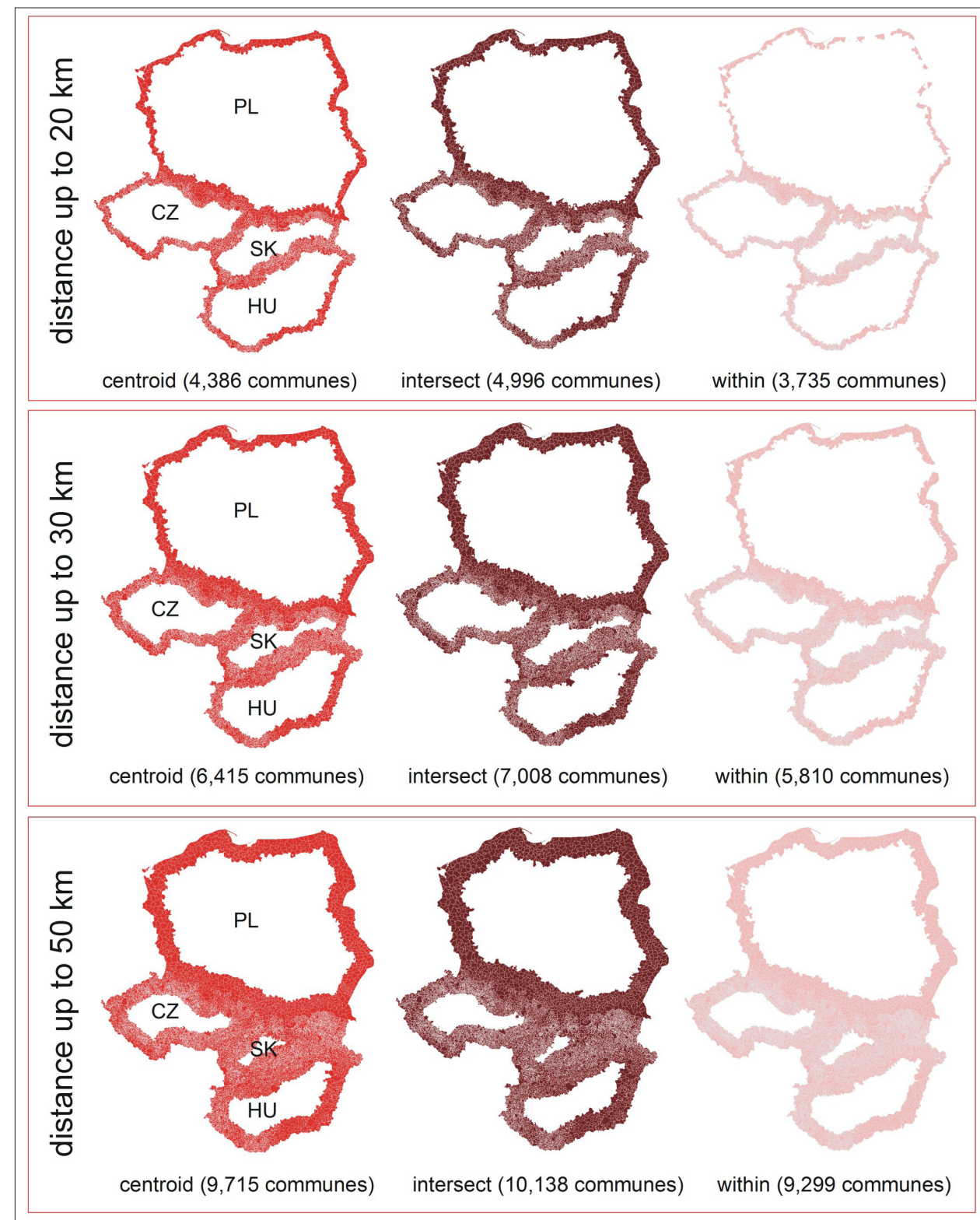

Fig. 1: Distance zones used in making the final selection of analyzed municipalities. Source: authors

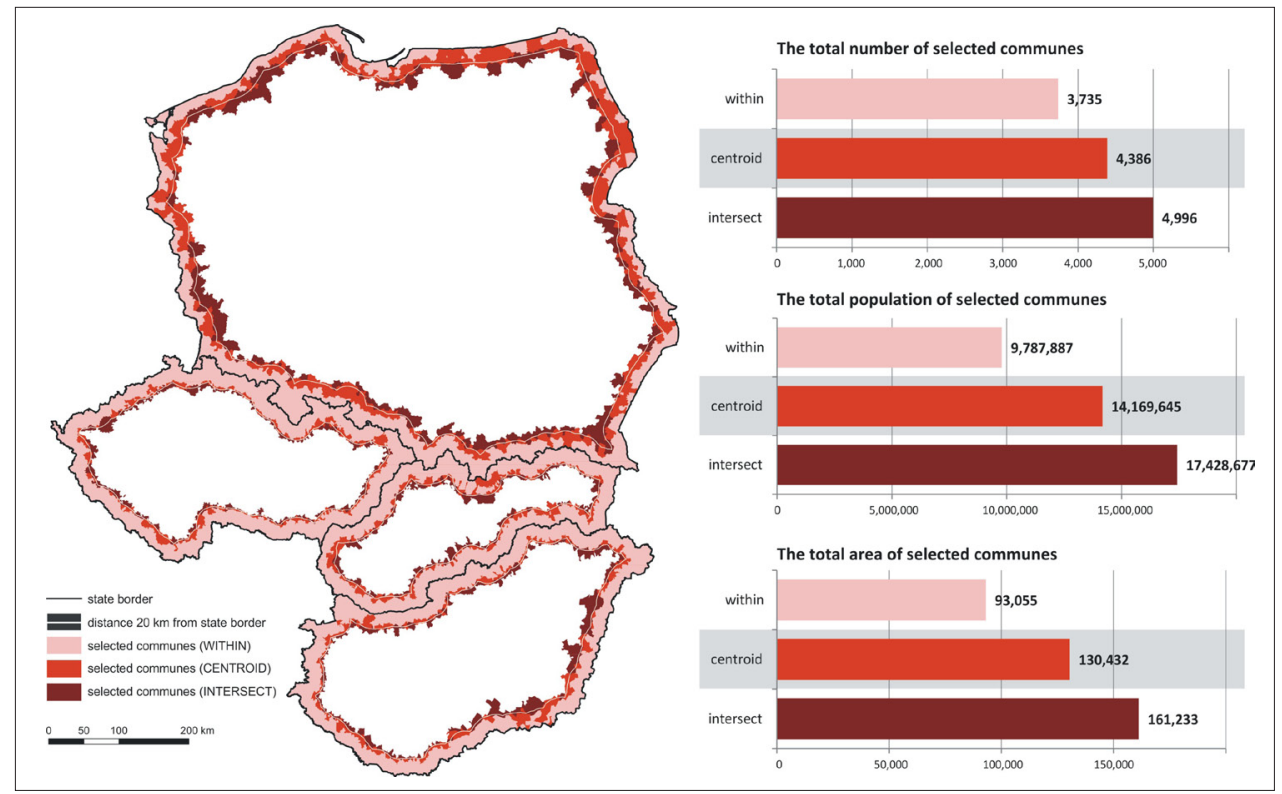

Fig. 2: Basic statistical indicators of the V4 countries borderlands. Source: authors 
'intersect', because of the potential inclusion of a large number of municipalities in the final selection. Moreover, in many cases this would be a very small part of the unit without any built-up area and thus, in most cases, uninhabited places. We are aware of the fact that when using the centroid position some possible limitation of the final selection of municipalities must be taken into account. Despite this, it seems to be the most appropriate method in terms of number of municipalities and spatial integrity of the analyzed area.

Figure 2 shows the basic statistical characteristics of the resulting set of municipalities that were analyzed in the empirical part of this paper. The final delimitation covers $24 \%$ of the total area of all municipalities in every country and $22 \%$ of their total population. Municipalities within the borderland represent $29 \%$ of the total number of municipalities in these countries.

\section{Data analysis}

As the borderland is usually examined at a small scale, such as border areas within a single state (Vaishar et al. 2011, 2013), or the cross-border areas of two or three countries (Kladivo et al., 2012; Wieckowski et al., 2012), or most recently borderland in terms of Euroregions (Turnock, 2002; Pikner, 2008; Popescu, 2008), it is then possible to use a broader scope of indicators for a more detailed analysis. In our case, we looked at the borderland in an unconventional way, and applied a smaller number of indicators, in the relatively large border areas of V4 countries, because of the significance of mutual comparison of these borderlands demonstrated by the Analysis of Variance (ANOVA) (see below). Although the scope of the indicators that we used does not encompass the full complexity of the changes and processes occurring in the borderland, detailed data of different economic and demographic variables reflect the key element of the borderland - population and its characteristics. Moreover, these data are recorded at the lowest hierarchical level, municipalities, which enable us to reveal the changes taking place in specific locations within the borderland and compare these changes with the localities on the opposite side of the border.

In addition to the common spatial level (municipalities) within all four countries, it was necessary to consolidate data for the same time period. Finally, we have chosen the years 2001 and 2011 for our analysis. First of all, a population census in all V4 countries took place in these years which means that data were also available at the lowest local level. At the same time, this period is interesting from the position of these countries with respect to the EU. While in 2001 none of them was a member of the EU, in 2004 all of these countries joined the EU as a part of the EU enlargement processes. Thus, 2011 is the first census year after joining the EU, providing a great possibility for analysis of several socio-economic parameters, as well as the impact of the integration of these countries into the European space.
The main variables that we used to calculate a number of other indicators were data relating to the population, population age structure, unemployment rate and net migration. We focused on the analysis of the changes that have occurred in the individual indicators in the period 2001-2011. The final selection of the variables in the period is shown in Tab. 2 .

With the population data, we analyzed: the population growth rate in the period 2001-2011; and data on the age structure were used to calculate the economic dependency ratio of the countries - the young age dependency ratio and old age dependency ratio, as well as the ageing index. Last but not least, the unemployment rate and crude rate of net migration were analyzed. For all indicators, we focused on the change in the period from 2001 to 2011.

Data on three variables (population, age structure and unemployment rate) were available for years 2001 and 2011 in all countries except for Poland, where data on unemployment (local level) were statistically recorded only since 2003. Data on net migration were analyzed for every single year in the period 2001-2011, except for Hungary, where the initial data were available from 2002 only. Table 3 shows the indicators and the corresponding relations used between them.

The data of all indicators have undergone tests of differences in group means (using the Analysis of Variance: ANOVA) in order to determine their statistical significance, using Tukey's HSD Test in a One-Way ANOVA which enables us to determine similarity or difference of changes in individual indicators between each of the V4 countries. The detailed methodology of ANOVA can be found in Rogerson (2001) or Miller and Haden (2006). It should be stressed that we tested the data of indicators for all territorial units (municipalities) in the sample of V4 countries, as well as particularly for selected units (municipalities within the borderland). Our task was to test the following hypotheses:

- The change of a particular indicator in the period 20012011 was the same or very similar in the borderland of V4 countries (null hypothesis);

- The change of a particular indicator in the period 20012011, with respect to the borderland of V4 countries, varies from state to state (an alternative hypothesis).

Table 4 demonstrates that the analysis (single-factor ANOVA model) shows very low probability values of all indicators $(\mathrm{P}$ values $<0.01)$. Therefore, the general null hypothesis can be rejected and we can accept the alternative hypothesis. Since the V4 countries have different mean values of specific indicators (in terms of change in the period 20012011), they are statistically significant and it is therefore appropriate to subject them to a deeper spatial analysis.

\section{Results}

The most significant results of our borderland analysis with a focus on the changes in the selected indicators in the period 2001-2011 are discussed in this section. For the purposes

\begin{tabular}{|l|c|c|c|c|}
\hline \multirow{2}{*}{\multicolumn{1}{|c|}{ Country }} & \multicolumn{4}{|c|}{ Variables } \\
\cline { 2 - 5 } & Population & Net migration & Age structure & Unemployment rate \\
\hline Poland & 2001,2011 & $2001-2011$ & 2001,2011 & 2003,2011 \\
\hline Czech Republic & 2001,2011 & $2001-2011$ & 2001,2011 & 2001,2011 \\
\hline Slovakia & 2001,2011 & $2001-2011$ & 2001,2011 & 2001,2011 \\
\hline Hungary & 2001,2011 & $2002-2011$ & 2001,2011 & 2001,2011 \\
\hline
\end{tabular}

Tab. 2: Variables analyzed at a local level (municipalities) and the available years. Source: authors 


\begin{tabular}{|c|c|c|c|}
\hline \multirow{2}{*}{ Variables } & \multicolumn{3}{|c|}{ Summary and explanation of the relations } \\
\hline & Indicator & Relation & Notes \\
\hline Population & Population growth rate & $\frac{P\left(t_{2}\right)-P\left(t_{1}\right)}{P\left(t_{1}\right)}$ & $\begin{array}{l}\mathrm{P}(\mathrm{t} 2) \text { - population at the end of the period } \\
\mathrm{P}(\mathrm{t} 1) \text { - population at the beginning of the period }\end{array}$ \\
\hline Net migration & Crude rate of net migration & $\frac{\left(P_{i}-P_{e}\right)}{P_{m}} * 1000$ & $\begin{array}{l}\mathrm{Pi} \text { - number of immigrants } \\
\mathrm{Pe} \text { - number of emigrants } \\
\mathrm{Pm} \text { - mid-year population }\end{array}$ \\
\hline \multirow{4}{*}{ Age structure } & Ageing index & $\frac{P_{65+}}{P_{14}} * 100$ & $\begin{array}{l}\text { P14 - population in pre-productive age } \\
\text { P65+ - population in post-productive age }\end{array}$ \\
\hline & Economic dependency ratio & $\frac{\left(P_{14}+P_{65+}\right)}{P_{15-64}} * 100$ & $\begin{array}{l}\text { P14 - population in pre-productive age } \\
\text { P15- } 64 \text { - population in productive age } \\
\text { P65+ - population in post-productive age }\end{array}$ \\
\hline & Young age dependency ratio & $\frac{P_{14}}{P_{15-64}} * 100$ & $\begin{array}{l}\text { P14 - population in pre-productive age } \\
\text { P15-64 - population in productive age }\end{array}$ \\
\hline & Old age dependency ratio & $\frac{P_{65+}}{P_{15-64}} * 100$ & $\begin{array}{l}\text { P15-64 - population in productive age } \\
\text { P65+ - population in post-productive age }\end{array}$ \\
\hline Unemployment & Unemployment rate & \multicolumn{2}{|c|}{$\begin{array}{l}\text { Data available in the databases of Statistical Offices of Slovakia, Czech Republic, } \\
\text { Poland and Hungary* }\end{array}$} \\
\hline
\end{tabular}

Tab. 3: Indicators and the corresponding relations used in the analysis of borderlands (Note: * Links to the websites of the Statistical Offices are listed in the References)

Source: Jurčová (2005), edited by authors

\begin{tabular}{|l|c|c|}
\hline \multicolumn{2}{|c|}{ Analysis of Variance (ANOVA) - single factor } \\
\hline Indicator (change between 2001-2011) & All units in V4 countries & The borderland of V4 countries \\
& p-value & $1.4024 \mathrm{E}-115$ \\
\hline Population growth rate & $1.0265 \mathrm{E}-297$ & $1.68487 \mathrm{E}-67$ \\
\hline Crude rate of net migration & $5.2461 \mathrm{E}-305$ & 0.000102459 \\
\hline Ageing index & $3.94077 \mathrm{E}-18$ & $8.2863 \mathrm{E}-22$ \\
\hline Economic dependency ratio & $1.7662 \mathrm{E}-138$ & $3.38553 \mathrm{E}-40$ \\
\hline Young age dependency ratio & $6.7398 \mathrm{E}-298$ & $6.82028 \mathrm{E}-11$ \\
\hline Old age dependency ratio & $4.01265 \mathrm{E}-28$ & 0.009808922 \\
\hline Unemployment rate & $1.58971 \mathrm{E}-23$ & \\
\hline
\end{tabular}

Tab. 4: Analysis of Variance (ANOVA) of individual indicators. Source: edited by authors

of our research, we analyzed seven socio-economic indicators (see Tab. 3) which demonstrate dissimilar development of the borderland. One of the key research questions was to determine differences and similarities in the development of geographically differentiated borderlands (along the internal as well as external border of the EU), as well as to answer the questions whether certain changes along the border (within the country) and changes between neighbouring areas on the both sides of the border (cross-border relations), tend to overlap and to what extent. Moreover, we try to examine where the situation has improved and where, on the contrary, the values of indicators have become even worse.

The ANOVA results demonstrated the significance of the selected indicators and their relevance to the study of the borderlands of the V4 countries. Using the Tukey HSD Test in the analysis, we were able to distinguish the differences in the mean values of indicators between each pair of states within the V4 countries. From Table 5 we can clearly see that in all indicators, except the Young age dependency ratio (whether we consider all units or only the borderland of V4 countries), at least one pair of states is characterized by similar mean values of the change in the specific indicator. Moreover, with the exception of Population growth rate, both similarities and differences in the change of specific indicators (whether we consider all units or only the borderland of V4 countries) are subject to change. These results provide sufficient reason to have these borderland areas cartographically analyzed in detail.

The first indicator was the Population growth rate (Fig. 3), referring to the extent to which the population of a certain area (in this case municipality) increases or decreases. The most significant change was along the Hungarian borderland, where there was a decline in population. An exception is the northwestern part of the SK/HU borderland, especially the 


\begin{tabular}{|c|c|c|c|c|c|c|c|c|}
\hline \multicolumn{9}{|c|}{ Pair-Wise Comparisons via Tukey HSD Test } \\
\hline $\begin{array}{c}\text { Indicator } \\
\text { (change between 2001-2011) }\end{array}$ & \multicolumn{4}{|c|}{ All units inV4 countries } & \multicolumn{4}{|c|}{ The borderland of V4 countries } \\
\hline \multirow[t]{4}{*}{ Population growth rate } & & HU & PL & SK & & HU & PL & SK \\
\hline & $\mathrm{CZ}$ & $\mathrm{P}<.01$ & $\mathrm{P}<.01$ & $\mathrm{P}<.01$ & $\mathrm{CZ}$ & $\mathrm{P}<.01$ & $\mathrm{P}<.01$ & $\mathrm{P}<.01$ \\
\hline & $\mathrm{HU}$ & & $\mathrm{P}<.01$ & $\mathrm{P}<.01$ & $\mathrm{HU}$ & & $\mathrm{P}<.01$ & $\mathrm{P}<.01$ \\
\hline & PL & & & $\mathrm{n} / \mathrm{s}$ & PL & & & $\mathrm{n} / \mathrm{s}$ \\
\hline \multirow[t]{4}{*}{ Crude rate of net migration } & & $\mathrm{HU}$ & PL & SR & & HU & PL & SR \\
\hline & $\mathrm{CZ}$ & $\mathrm{n} / \mathrm{s}$ & $\mathrm{P}<.01$ & $\mathrm{P}<.05$ & $\mathrm{CZ}$ & $\mathrm{P}<.01$ & $\mathrm{P}<.01$ & $\mathrm{n} / \mathrm{s}$ \\
\hline & HU & & $\mathrm{P}<.01$ & $\mathrm{n} / \mathrm{s}$ & HU & & $\mathrm{n} / \mathrm{s}$ & $\mathrm{P}<.01$ \\
\hline & PL & & & $\mathrm{P}<.01$ & PL & & & $\mathrm{P}<.01$ \\
\hline \multirow[t]{4}{*}{ Ageing index } & & $\mathrm{HU}$ & PL & SR & & $\mathrm{HU}$ & PL & SR \\
\hline & $\mathrm{CZ}$ & $\mathrm{P}<.01$ & $\mathrm{n} / \mathrm{s}$ & $\mathrm{n} / \mathrm{s}$ & $\mathrm{CZ}$ & $\mathrm{n} / \mathrm{s}$ & $\mathrm{n} / \mathrm{s}$ & $\mathrm{n} / \mathrm{s}$ \\
\hline & HU & & $\mathrm{P}<.01$ & $\mathrm{P}<.01$ & HU & & $\mathrm{n} / \mathrm{s}$ & $\mathrm{P}<.01$ \\
\hline & PL & & & $\mathrm{n} / \mathrm{s}$ & PL & & & $\mathrm{n} / \mathrm{s}$ \\
\hline \multirow[t]{4}{*}{ Economic dependency ratio } & & $\mathrm{HU}$ & PL & SR & & $\mathrm{HU}$ & PL & SR \\
\hline & $\mathrm{CZ}$ & $\mathrm{P}<.01$ & $\mathrm{P}<.01$ & $\mathrm{P}<.01$ & $\mathrm{CZ}$ & $\mathrm{P}<.01$ & $\mathrm{P}<.01$ & $\mathrm{P}<.01$ \\
\hline & $\mathrm{HU}$ & & $\mathrm{P}<.01$ & $\mathrm{P}<.01$ & $\mathrm{HU}$ & & $\mathrm{n} / \mathrm{s}$ & $\mathrm{P}<.01$ \\
\hline & PL & & & $\mathrm{n} / \mathrm{s}$ & PL & & & $\mathrm{n} / \mathrm{s}$ \\
\hline \multirow[t]{4}{*}{ Young age dependency ratio } & & $\mathrm{HU}$ & PL & SR & & $\mathrm{HU}$ & PL & SR \\
\hline & $\mathrm{CZ}$ & $\mathrm{P}<.01$ & $\mathrm{P}<.01$ & $\mathrm{P}<.01$ & $\mathrm{CZ}$ & $\mathrm{P}<.01$ & $\mathrm{P}<.01$ & $\mathrm{P}<.01$ \\
\hline & HU & & $\mathrm{P}<.01$ & $\mathrm{P}<.01$ & HU & & $\mathrm{P}<.01$ & $\mathrm{P}<.01$ \\
\hline & PL & & & $\mathrm{P}<.01$ & PL & & & $\mathrm{P}<.01$ \\
\hline \multirow[t]{4}{*}{ Old age dependency ratio } & & $\mathrm{HU}$ & PL & SR & & $\mathrm{HU}$ & PL & SR \\
\hline & $\mathrm{CZ}$ & $\mathrm{P}<.05$ & $\mathrm{P}<.01$ & $\mathrm{P}<.01$ & $\mathrm{CZ}$ & $\mathrm{P}<.01$ & $\mathrm{n} / \mathrm{s}$ & $\mathrm{P}<.01$ \\
\hline & $\mathrm{HU}$ & & $\mathrm{n} / \mathrm{s}$ & $\mathrm{P}<.01$ & $\mathrm{HU}$ & & $\mathrm{n} / \mathrm{s}$ & $\mathrm{n} / \mathrm{s}$ \\
\hline & PL & & & $\mathrm{P}<.01$ & PL & & & $\mathrm{P}<.01$ \\
\hline \multirow[t]{4}{*}{ Unemployment rate } & & HU & PL & SR & & $\mathrm{HU}$ & PL & SR \\
\hline & $\mathrm{CZ}$ & $\mathrm{P}<.01$ & $\mathrm{P}<.01$ & $\mathrm{P}<.01$ & $\mathrm{CZ}$ & $\mathrm{n} / \mathrm{s}$ & $\mathrm{P}<.01$ & $\mathrm{n} / \mathrm{s}$ \\
\hline & $\mathrm{HU}$ & & $\mathrm{n} / \mathrm{s}$ & $\mathrm{P}<.01$ & $\mathrm{HU}$ & & $\mathrm{P}<.05$ & $\mathrm{P}<.01$ \\
\hline & PL & & & $\mathrm{P}<.01$ & PL & & & $\mathrm{P}<.01$ \\
\hline
\end{tabular}

Tab. 5: Pair-wise comparisons using Tukey's HSD Test in One-Way ANOVA model (Note: $n / s=$ non-significant) Source: edited by authors

area between Bratislava and Budapest, where there are mostly stationary or progressive types of municipalities. One of the reasons could be the existence of the suburban zone in the hinterland of these capitals but it can also be affected by other unspecified factors. Significantly regressive areas can be found also along the eastern PL borderland and northeastern SK borderland. On the other hand, a significant cluster of progressive municipalities is concentrated along the SK/PL borderland.

Results of this analysis illustrated that the borderland has demonstrated high variability and diversity in all V4 countries. Only values between Slovakia and Poland (hence within the PL/SK borderland) show some similarity; however, distributions within specific areas or regions within the borderland differ from each other. Thus, while in certain parts of the borderland a cluster of stationary, regressive or progressive municipalities occur, ultimately, their overall average appears to be quite similar.

Since the development of the population is also affected by migration processes, the Crude rate of net migration (Fig. 4) was another variable in our analysis. The analysis revealed that the borderland can have a significant impact in terms of this indicator. While in all units (understood as all municipalities of the V4 countries), the mean values of the indicator were similar only between the Czech Republic and Hungary and between Hungary and Slovakia, this similarity disappeared when analyzing the borderland of these countries. Conversely, while in all units there was a slightly differentiated change in the mean values of this indicator (e.g. between the Czech Republic and Slovakia, or Poland and Hungary), in the borderland of these countries the values of the indicator were relatively similar. Their spatial differentiation is further demonstrated in Figure 4.

Basically, the entire borderland along the eastern (external) border of the EU recorded a decline in net migration, with the exception of the SK/HU borderland with minor changes only. Similarly, a downward trend can be seen in some areas of the PL borderland, especially in the eastern borderland, the eastern part of the PL/CZ and PL/SK borderland. Central parts of the PL/SK borderland and the southeastern SK/HU borderland, however, are characterized by greater stability in terms of this indicator. On the other hand, in localities near Bratislava there was even an increase in net migration resulting partially from labour migration into this region. 
The other four indicators are based on age structure. The first one is the Ageing index (Fig. 5), which increased during the period 2001-2011, resulting in population ageing in most of the analyzed borderland. The exception is the southern, eastern and northeastern SK borderland where, in contrast, the majority of municipalities experienced the opposite trend. One of the reasons could be a higher concentration of the Roma ethnic group in this area, characterized by a higher birth rate and lower average age, meaning that the

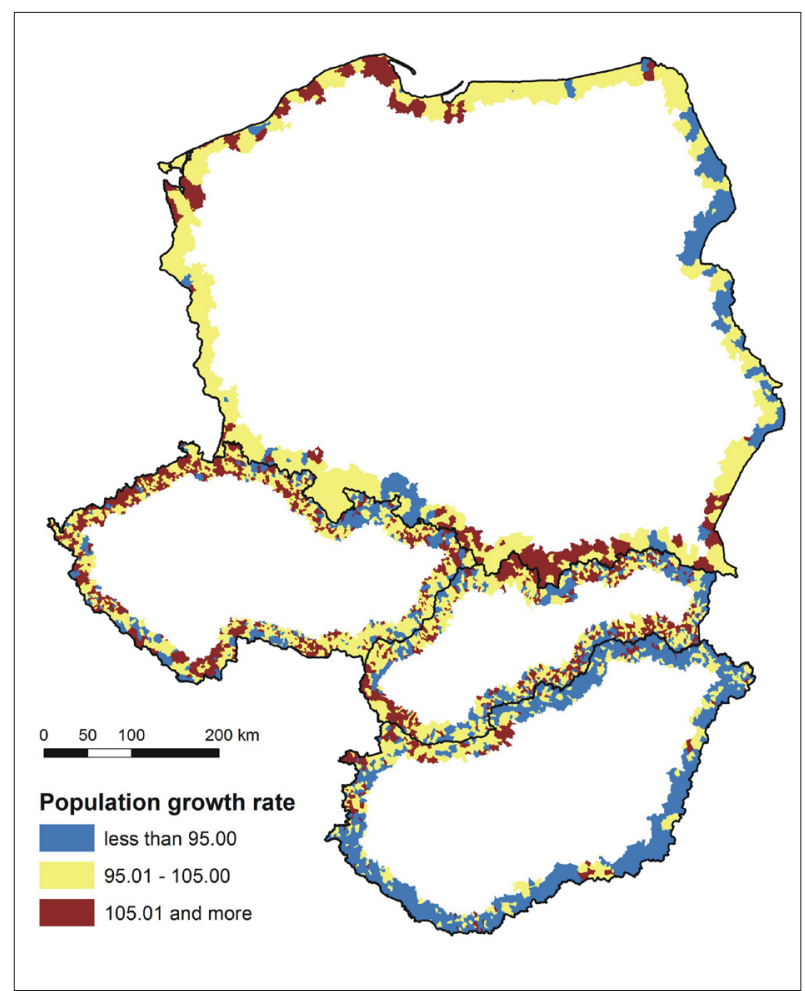

Fig. 3: Population growth rate. Source: authors

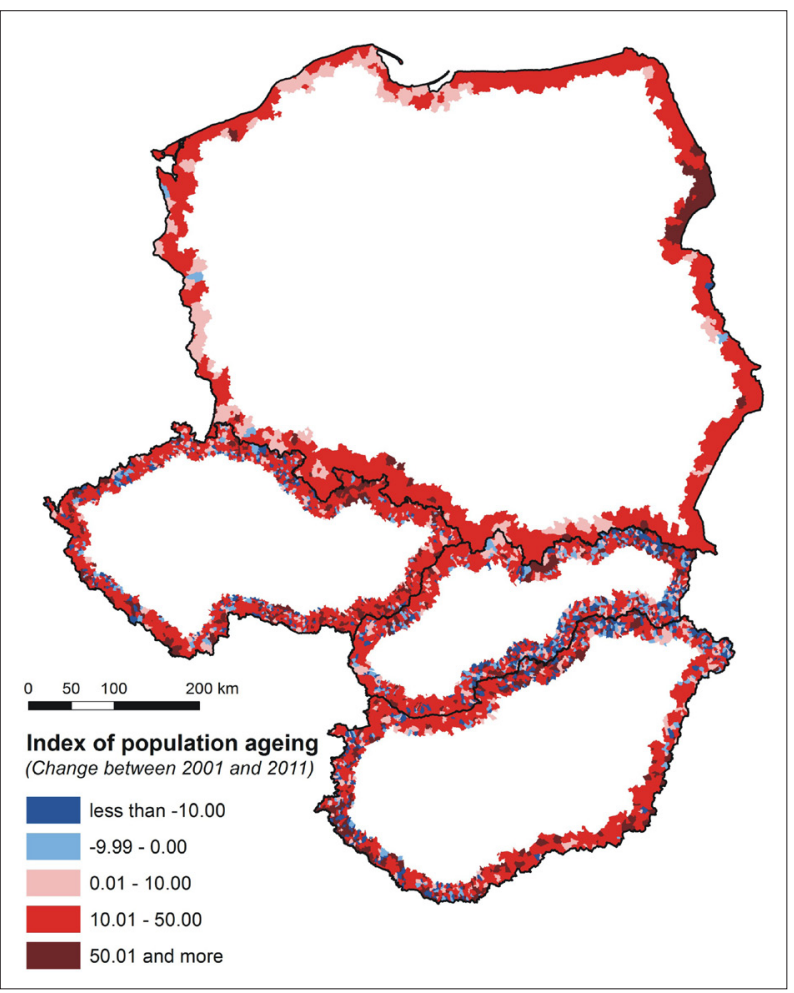

Fig. 5: Ageing index. Source: authors population is getting younger with the 'bottom-up' approach. In fact, it is the ageing process that can be considered as the most significant and, nowadays, also the most critical consequence of the current population processes that can be also recognised in the borderland.

Other indicators which use data on age structure are the Economic dependency ratio (Fig. 6), Young age dependency ratio and Old age dependency ratio. In the period 20012011 there was a slight increase of burden on the working

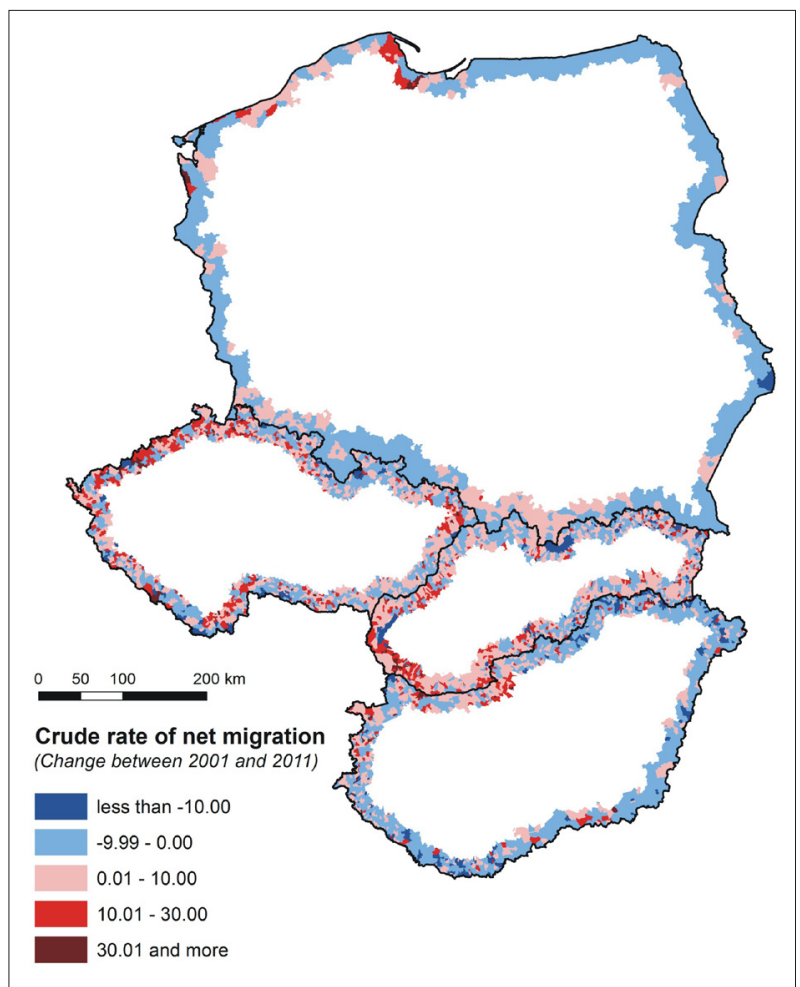

Fig. 4: Crude rate of net migration. Source: authors

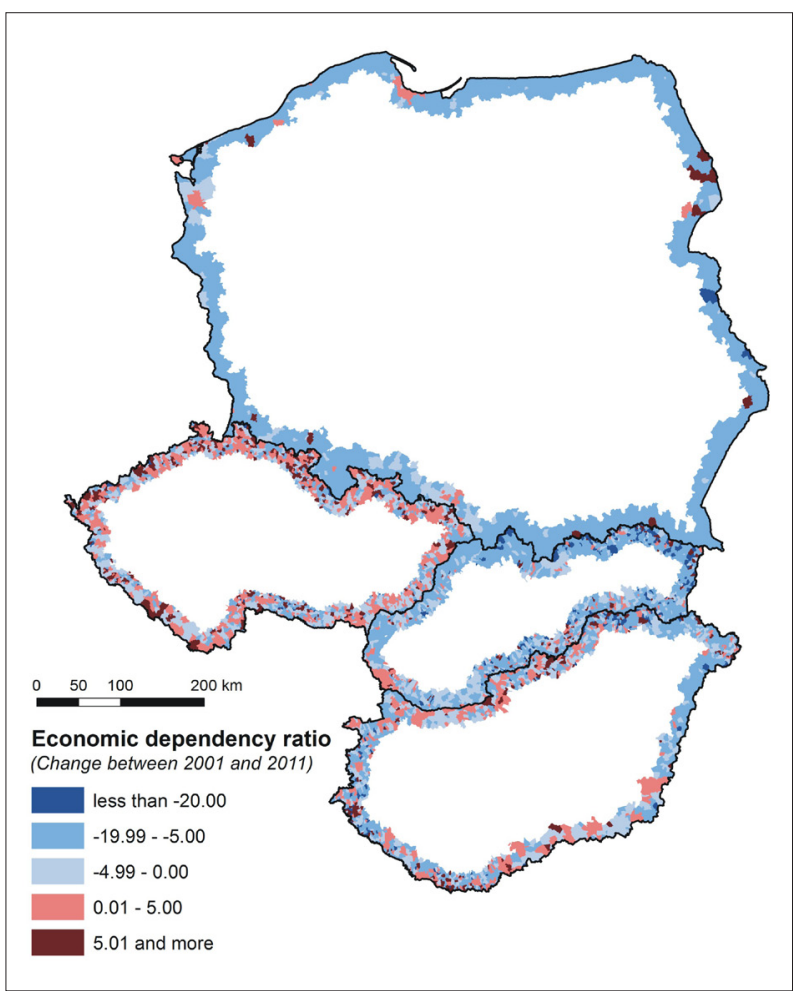

Fig. 6: Economic dependency ratio. Source: authors 
population (productive age group) almost all over the CZ borderland and in the northwestern and southeastern parts of the HU borderland. In Bratislava and its surroundings the situation has evolved similarly, and the values of the economic dependency ratio have also increased compared to 2001 (a similar trend was also recorded in other capitals and the major cities of Poland and Hungary). As a consequence of the reduction in the natural increase across the borderland, the young age dependency ratio also decreased, while the influence of population ageing was reflected in the increase of the old age dependency ratio, especially in the $\mathrm{CZ}$ borderland, south parts of the $\mathrm{HU}$ borderland, and northeastern SK/HU borderland.

In relation to the indicators of age structure, this analysis shows that with the exception of Hungary and Slovakia, the mean values of Ageing index between each pair of states within the V4 countries were very similar. On the other hand, in the values of the Young age dependency ratio significantly different values were recorded (see Tab. 5 above). Moreover, as is clear from Figure 6, the analysis also showed that the changes in the value of the Economic dependency ratio in the borderland of Poland and Slovakia are relatively similar.

Last but not least, we analyzed the change in Unemployment rate (Fig. 7). The most positive change of this indicator was in almost all of the entire PL borderland as well as the SK borderland, except for the area located in its southeastern part where unemployment remained at the same level as 10 years previously or even declined. A slight increase was recorded along the CZ borderland, except for the northwestern part of CZ/DE borderland and the northeastern $\mathrm{CZ} / \mathrm{PL} / \mathrm{SK}$ borderland, and at the same time in the HU/AT (Austrian) borderland and the HU/SK borderland. The most significant rise of unemployment rate was in the central parts of the HU/SK borderland.

Resulting from the analysis of Unemployment rate, it is possible to follow a similar trend as in the Crude rate of net migration. While in all units the mean values of the indicator

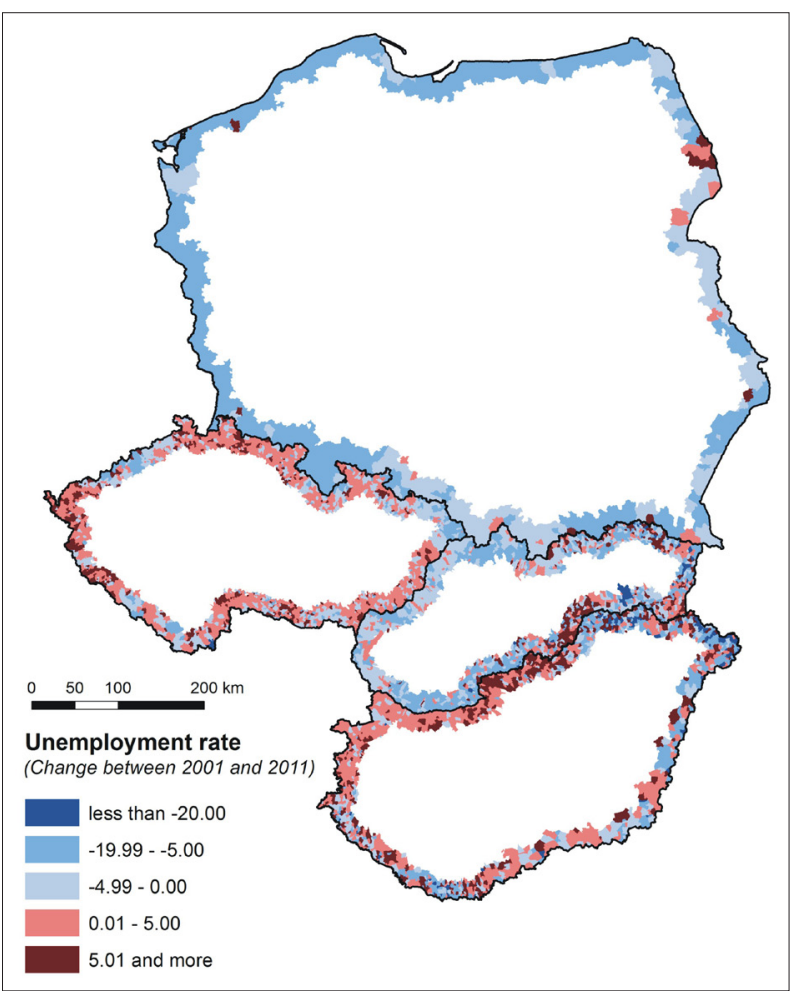

Fig. 7: Unemployment rate. Source: authors were similar only between Poland and Hungary, greater differences appeared when analysing the borderland of these countries. Conversely, the values of the indicator were relatively similar between the Czech Republic and Hungary, as well as between the Czech Republic and Slovakia.

\section{Concluding discussion}

Despite de-bordering processes, as we pointed out in our study, borders and the borderland remain to play an important role in academic research. Thus, a number of authors are devoted to this phenomenon from different aspects. As already emphasized in the earlier work of Anderson and O'Dowd (1999), the importance of borders and borderland, as well as their geographic location, is changing significantly in space and time. Such diversity is well expressed in their statement that "they (meaning borders) are at once gateways and barriers to the 'outside world', protective and imprisoning areas of opportunity and/or insecurity, zones of contact and/or conflict, of co-operation and/or competition, of ambivalent identities and/or the aggressive assertion of difference" (Anderson and O’Dowd, 1999: 595).

Moreover, under the influence of globalization processes, the borderland becomes a particularly interesting area for research. Globalization becomes an argument that points to a kind of borderless and deterritorialized world, and thus allows the opening of borders that divided us previously (Newman, 2006).

Even now, the presence of boundaries can have a different influence on the area in the vicinity of the borders, the borderland. The borderlands differ from each other in their status so much that we can even recognize several types of borderland. This is especially the case if we take into account the change in the nature of the borderland, caused by the EU enlargement process, which brought together countries with different levels of economic development and integration, resulting in increased regional disparities. Spatial characteristics of the borderland of the EU have changed so much that many of these areas have become peripheral. This is particularly a problem of the eastern (external) borderland of the EU, while the western borderland represents, due to mitigation of its borders, a rather open space for cooperation in the area on both sides of the border (Xheneti et al., 2012).

In our reasearch, we have focused on the analysis of the V4 countries, whose borders and borderlands have played an important role not only in the past (the Iron Curtain), but also today (as the eastern, external border of the EU). We were interested in how the borderlands of these countries have developed over time, especially in relation to the selected group of indicators. In particular, we focused on both changes along the border (within the country) and changes between neighbouring areas on both sides of the border (cross-border relations). Using an Analysis of Variance model, we have shown the significance of selected indicators and their relevance to the study of the borderland of V4 countries, and thus we were able to determine similarities and differences in the changes of individual indicators within each of them. It is crucial, however, to highlight that although the analysis revealed homogeneity or heterogeneity of certain sets of indicators, this must still be regarded as a global analysis, which means that for detailed analysis of the adjacent regions across the border, further cartographic visualization and analysis of the indicators is required. 
Further results from the analysis showed that geographically different borderlands have undertaken several paths in their development, and that the change of a particular indicator in the period 2001-2011 varied from state to state. A negative change of values of almost all monitored indicators occurred in the north-eastern $\mathrm{CZ}$ / PL borderland (on the Czech side), the central part of HU/ SK borderland (on the Hungarian side), the southern part of the HU borderland, and the northern part of the eastern borderland of PL. In these areas in the period 2001-2011, the growth index declined and, in contrast, other indicators such as the ageing index, unemployment rate and the economic dependency ratio increased. Thus, these areas can be described as rather peripheral in relation to their situation in the group of selected indicators. Several authors have come to a similar conclusion, especially when talking about the CZ/PL borderland. For instance, Kladivo et al. (2012) described certain areas of the CZ/PL borderland as peripheral (especially mountainous rural areas with a population decline and an absence of major transport infrastructure and urban centers). On the other hand, the stronger peripheral position of the South Moravian borderland, as stressed by Vaishar et al. (2013), was not reflected in our analysis, although it is quite understandable since both studies are based on different delimitation criteria of the borderland.

In general, the most favorable changes in the value of indicators were recorded along the PL and SK borderland. Moreover, some areas within the borderland of these countries were identified by Johnson (2009) as the regions of prosperity (the triangle between $\mathrm{PL} / \mathrm{CZ} / \mathrm{DE}$ ) or zone of active cross-border cooperation (especially the PL/SK borderland) by Wieckowski et al. (2012).

The general peripheralization of the eastern (external) border of the EU was neither fully confirmed nor rejected in our analysis, since only two of the four negative-evolving areas were identified along the HU/RS (Serbia) and partially $\mathrm{PL} / \mathrm{BY}$ (Belarus) borderland. It would be interesting to follow the development of these and other indicators on the opposite side of the external border of the EU, in the borderland of non-EU countries such as Belarus and Ukraine, as well as along the northern borderland of Serbia and Bosnia and Herzegovina. Would such an analysis confirm the pronounced peripherialization of the external border of the EU? At this point in time, we can only argue about these and similar conclusions, especially due to current data availability. But a detailed analysis of the borderland is of vital importance and deserves more research attention. This would enrich the current research in the field of borders and borderlands and allow us to answer questions that have not yet been answered.

\section{Acknowledgements}

The paper was prepared as a part of research project APVV-0018-12 "Human geography and demography interactions, nodes and contradictions in time-space network" as well as with a support of the project VEGA 1/0391/15 "Urban agglomerations in the Slovak Republic". We would like to express our very great appreciation to Mrs. Catherine Dimmock-Benko, external teacher at the Department of Languages, for her willingness to provide the linguistic correction of this article, and also wish to thank the anonymous referees for their inspiring comments and suggestions on an earlier draft of this article.

\section{References:}

ANDERSON, J., O’DOWD, L. (1999): Borders, Border Regions and Territoriality: Contradictory Meanings, Changing Significance. Regional Studies, 33(7): 593-604.

BEST, U. (2007): Transgression as a Rule: German-Polish Cross-border Co-operation, Border Discourse and EUenlargement. Münster: Lit-Verlag.

BRENNER, N. (2000): Building 'Euro-regions': Locational Politics and the Political Geography of Neoliberalism in Post-unification Germany. European Urban and Regional Studies, 7(4): 319-345.

BRENNER, N. (2003): Metropolitan Institutional Reform and the Rescaling of State Space in Contemporary Western Europe', European Urban and Regional Studies, 10(4): 297-324.

BUFON, M. (2007): Border regions in a re-integrated Europe. Moravian Geographical Reports. 15(1): 2-13.

BUFON, M., MARKELJ, V. (2010): Regional policies and cross-border cooperation: new challenges and new development models in Central Europe. Romanian Review of Political Geography, 12(1): 18-28.

CENTRAL STATISTICAL OFFICE OF POLAND [online]. [cit. 15.06.2014] Available at: www.stat.gov.pl

CZECH STATISTICAL OFFICE [online]. [cit. 15.06.2014] Available at: www.czso.cz

DINGSDALE, A. (1999): Redefining Eastern Europe: A New Regional Geography of Post-Socialist Europe? Geography, 84(3): 204-221.

DOŁZBŁASZ, S. (2013): Cross-border co-operation in the Euroregions at the Polish-Czech and Polish-Slovak borders. European Countryside, 5(2): 102-114.

DŽUPINOVÁ, E. et al. (2008): Periférnost a priestorová polarizácia na území Slovenska. Bratislava, Geografika.

GUALINI, E. (2004): Integration, Diversity, Plurality: Territorial Governance and the Reconstruction of Legitimacy in a European 'Postnational' State, Geopolitics, 9(3): 542-563.

GREGORY, D. [ed.] (2009): The Dictionary of Human Geography. $5^{\text {th }}$ Edition.

HÄKLI, J. (2008): Re-bordering spaces. The Sage handbook of political geography.

HUNGARIAN CENTRAL STATISTICAL OFFICE [online]. [cit. 15.06.2014] Available at: www.ksh.hu

JACKSON, J., MOLOKOTOS-LIEDERMAN, L. [eds.] (2015): Nationalism, ethnicity and boundaries: conceptualising and understanding identity through boundary approaches. Routledge.

JEŘÁBEK, M., DOKOUPIL, J., HAVLÍČEK, T. (2004): České pohraničí-bariéra nebo prostor zprostředkování? Praha, Academia.

JOHNSON, C. M. (2009): Cross-border regions and territorial restructuring in central Europe room for more transboundary SPACE. European Urban and Regional Studies, 16(2): 177-191.

JOHNSON, C., JONES, R., PAASI, A., AMOORE, L., MOUNTZ, A., SALTER, M., RUMFORD, C. (2011): Interventions on rethinking 'the border' in border studies.Political Geography, 30(2): 61-69. 
JURČOVÁ, D. (2005): Slovník demografických pojmov. INFOSTAT, Bratislava.

KLADIVO, P., PTÁČEK, P. ROUBÍNEK, P., ZIENER, K. (2012): The Czech-Polish and Austrian-Slovenian borderlands - similarities and differences in the development and typology of regions. Moravian Geographical Reports, 20(3): 22-37.

KRÄTKE, S. (1999): Regional Integration or Fragmentation? The German-Polish Border: Region in a New Europe. Regional Studies, 33(7): 631-641.

MCDONAGH, J. (2002). Peripherality and the West of Ireland: The Need for Reevaluation? In: MCDONAGH, J. [ed.]: Economy, society, and peripherality: experiences from the West of Ireland (pp. 97-112). Galway, Arlen House.

MILLER, J., HADEN, P. (2006): Statistical Analysis with the General Linear Model. Creative Commons Attribution.

NELLES, J., DURAND, F. (2012): Political rescaling and metropolitan governance in cross-border regions: comparing the cross-border metropolitan areas of Lille and Luxembourg. European Urban and Regional Studies, 21(1): 104-122.

NEWMAN, D. (2006): The lines that continue to separate us: Borders in a 'borderless' world. Progress in Human Geography. 30(1): 143-161.

NEWMAN, D., PAASI, A. (1998): Fences and neighbours in the postmodern world: boundary narratives in political geography. Progress in human geography, 22(2): 186-207.

O’DOWD, L. (2001): State borders, border regions band the construction of European identity. In: KOHLI, M., NOVAK, M. [eds.]: Will Europe work?: integration, employment and the social order (pp. 95-110). Routledge.

PAASI, A. (1999): Boundaries as Social Practice and Discourse: the Finnish-Russian Border. Regional Studies, 33(7): 669-680.

PAASI, A. (2002): Regional Transformation in the European Context: Notes on Regions, Boundaries and Identity. Space and Polity, 6(2): 197-201.

PAASI, A. (2012): Border studies reanimated: going beyond the territorial/relational divide. Environment and Planning A, 44(10): 2303-2309.
PERKMANN, M. (2003): Cross-Border Regions in Europe Significance and Drivers of Regional Cross-Border Co-Operation. European Urban and regional studies, 10(2): 153-171).

PIKNER, T. (2008): Reorganizing Cross-Border Governance Capacity The Case of the Helsinki-Tallinn Euregio. European Urban and Regional Studies, 15(3): 211-227.

POPESCU, G. (2008): The conflicting logics of cross-border reterritorialization: Geopolitics of Euroregions in Eastern Europe. Political Geography, 27(4): 418-438.

RAJČÁKOVÁ, E. (2005): Bratislava-Trnava Region. Within the Golden Triangle Vienna-Bratislava-Győr. Adult Education in European Border Regions (pp. 104-108). Research Society Burgenland, Eisenstad.

ROGERSON, P. (2001): Statistical methods for geography. Sage. STATISTICAL OFFICE OF THE SLOVAK REPUBLIC [online]. [cit. 15.06.2014] Available at: www.statistics.sk

STRYJAKIEWICZ, T. (1998): The changing role of border zones in the transforming economies of East-Central Europe: The case of Poland. GeoJournal, 44(3): 203-213.

TOKES, T., LENKEY, G. (2013): Role of Euroregions in the Development of Border Peripheries. Annals of the University of Oradea, Geography Series/Analele Universitatii din Oradea, Seria Geografie, 23(2): 229-235.

TURNOCK, D. (2002): Cross-border cooperation: A major element in regional policy in East Central Europe. The Scottish Geographical Magazine, 118(1): 19-40.

VAISHAR, A. et al. (2011): Současný stav a vývojové tendence jihomoravského venkova. Brno, Mendelova univerzita.

VAISHAR, A. et al. (2013): South-Moravian Rural Borderland. European Countryside, 5(2): 115-132.

VARRÓ, K. (2014): Spatial Imaginaries of the Dutch - German - Belgian Borderlands: A Multidimensional Analysis of Cross-Border Regional Governance. International Journal of Urban and Regional Research, 38(6): 2235-2255.

WIECKOWSKI, M. et al. (2012): Pol'sko-slovenské pohraničie z hladiska dopravnej dostupnosti a rozvoja cestovného ruchu. Warszawa-Bratislava: IGiPZ PAN.

XHENETI, M., SMALLBONE, D., WELTER, F. (2012): EU enlargement effects on cross-border informal entrepreneurial activities. European Urban and Regional Studies, 20(3): 314-328. 